\title{
TPACK MODEL BASED INSTRUCTION IN TEACHING WRITING: AN ANALYSIS ON TPACK LITERACY
}

\author{
Salasiah Ammade \\ Makassar State University, Indonesia \\ Email:evisalasiah@gmail.com \\ Murni Mahmud \\ Makassar State University, Indonesia \\ Email:murnimahmud@unm.ac.id \\ Baso Jabu \\ Makassar State University, Indonesia \\ Email:basojabu@unm.ac.id \\ Suradi Tahmir \\ Makassar State University, Indonesia \\ Email:suraditahmir@unm.ac.id
}

DOI: $10.26858 /$ ijole.v4i2.12441

\begin{abstract}
Acknowledging prior knowledge on technology, pedagogy, and content of lecturers in this early stage of developmental research is assuming important as basic data for further steps in designing TPACK model-based instruction in teaching writing. Therefore, having investigation on TPACK literacy of the lecturers will complete the data needed in this study. This paper presents an analysis of Technological Pedagogical and Content Knowledge (TPACK) literacy among lecturers at Universitas Muhammadiyah Parepare, Indonesia. In finding the data, the TPACK survey of Schmidt, Baran, Thomson (2009) was applied by having little modification on it. The main points on the survey were about Technological Knowledge (TK), Pedagogical Knowledge (PK), Content Knowledge (CK), and TPACK. In gaining the data, the questionnaire as the research instrument was distributed to lecturers in the English Education Department, and their responses were analyzed quantitatively. This research was conducted at Universitas Muhammadiyah Parepare, South Sulawesi province, Indonesia. The questionnaire results showed that the lecturers' levels of literacy on technology, pedagogy, content knowledge, and TPACK are on moderate stage. They can be categorized as good level on overall TPACK literacy, but need to improve in order to achieve better results by having more practice or learning workshops.
\end{abstract}

Keywords: TPACK, literacy, analysis, development, writing

\section{INTRODUCTION}

Populations globally are obtaining new skills and competencies, driven by the need to survive the fast-changing development of technology. The education sector plays a main role in preparing societies to face a technology-oriented working environment (Altun \& Akyildiz, 2017). Therefore, integrating technology into the classroom has been considered deeply in order to create more conducive environments for improving teaching and learning.
The rapid growth of modern technology creates new challenges in various professional development and practice arenas, including the education sector. Adopting new or innovative technology in teaching is part of the challenge in the current technological era. However, the mere adoption of technology will not be enough to meet learners' needs. Teachers' competencies in integrating technology in their teaching can form as a bridge to support the learners in maximizing their 
achievements. Therefore, preparing teachers for Information and Communication Technology (ICT) integration in class could support them by sparking their professionalism. Research by Khan (2014) supports this notion by presenting a model of Technological, Pedagogical, and Content Knowledge (TPACK) as part of teachers' professional development in Bangladesh.

In addition, Chai, Koh and Tsai (2010) carried out encouraging research, measuring the perceived development of teachers' knowledge of technology, pedagogy, and content. Using the TPACK questionnaire of Schmidt, Baran, Thompson, Mishra, Koehler, \& Shin (2009), their findings revealed that knowledge in these three areas are all significant predictors of teachers' preparations for using technology for teaching.

Teaching in $21^{\text {st }}$ century schools has developed into a more complex and difficult profession as students are exposed to much digital technology, and are highly adept in using new technologies (Altun \& Akyildiz, 2017, p. 468). Consequently, teachers play a vital role in education settings, where they are expected to integrate technology into instructional tasks in an effective and suitable way. Mouza, Karchmer-Klein, Nandakumar, Ozden, \& Hu (2014) were among researchers who had identified ways to encourage the technological and pedagogical skills of teachers for better teaching. Teachers here are expected to integrate technology with pedagogy and content; in other words, they need to be competent in three areas of effective teaching: pedagogy, content of the area, and the use of technology. Mishra and Koehler (2006) underlined this approach by developing a framework for teacher knowledge that focuses on technological integration known as Technological, Pedagogical Content Knowledge (TPACK), and it was inspired by Shulman's (1986) theory of Pedagogical Content Knowledge (PCK).

TPACK as a model of technological integration explores teachers' comprehension of how ICT can be used as pedagogical tool in teaching and learning. Altun \& Akyildiz (2017, p. 469) stated that the basis of TPACK is to create effective teaching with technology. This entails deep understanding of the concept of technology use, of pedagogical technique - using technologies in constructive ways to generate teaching content - of what makes learning easy or difficult, and of how technologies can remedy the problems students face.

The above research findings on TPACK show that the framework has been considered a part of making teaching effective. The framework merges three core areas of knowledge - technology, pedagogy and content - into one unit that teachers need in this digital era. However, research on TPACK for certain skills in language teaching is still very limited, this research will fill the gap by analyzing the TPACK literacy of lecturers in the English education department at Universitas Muhammadiyah, Parepare.

Investigating technological, pedagogical and content knowledge (TPACK) literacy of lecturers in this study is considered essential in gauging their overall TPACK literacy. Obtaining data on their TPACK literacy makes it easier to devise a designed model of teaching using the TPACK model, and to produce comprehensive pedagogical instructions. The survey of TPACK distributed in this research was taken from the work of Schmidt, Baran, Thompson, Mishra, Koehler, \& Shin (2009), with a focus on Technology Knowledge (TK), Content Knowledge (CK), Pedagogical Knowledge (PK), and combined Technological, Pedagogical, Content Knowledge (TPACK).

\section{METHOD}

This research applied a quantitative approach as its research design. The study was conducted at Universitas Muhammadiyah Parepare, South Sulawesi province, Indonesia. The university was chosen as the setting for this research because the main aim of this study was to develop a 
teaching model of writing that integrates media and technology as part of quality improvements in education. In addition, it supports the university goal of being advanced in integrating technology into teaching.

Purposive sampling was chosen in selecting the sample. Kumar (2005, p. 62) defined purposive sampling as a nonprobability sampling in which the primary consideration is the judgement of the researcher as to which sample can provide best information to achieve the objectives of the study. Therefore, the research sample chosen comprised lecturers in English Education at Universitas Muhammadiyah Parepare who are involved in writing courses; their knowledge on teaching writing was considered representative of data needed in the study. A total of 14 lecturers participated.

Questionnaire is a popular research instrument for collecting educational research data. It is extensively employed to collect data about phenomena that cannot be observed directly, e.g. interests, opinions, values, experience, and the like (Gall, Gall, $\&$ Borg, 2003). In this study, the questionnaire was distributed to lecturers with experience in teaching writing. The TPACK survey distributed in this research was taken from the work of Schmidt, Baran, Thompson, Mishra, Koehler, \& Shin (2009), and focused on Technology Knowledge (TK), Content Knowledge (CK), Pedagogical Knowledge (PK), and Technological, Pedagogical, Content Knowledge (TPACK). The data from questionnaires was measured using SPSS 21.0, and displayed in the form of charts.

\section{RESULTS}

\section{Demographic Information}

Of the 14 lecturers who undertook the survey, ten were male and four were female. The subjects are lecturers in the English Education Department, aged between 30 and 50. Their education major is English, with the area of specialization teaching English as a foreign language. None of them have completed an educational computing minor, but they have computer good literacy.

\section{Technology Knowledge (TK)}

In this part, there are seven questions on technology knowledge, with answer options strongly disagree (SD), disagree (D), neither agree nor disagree $(\mathrm{N})$, agree $(\mathrm{A})$, and strongly agree (SA). The findings on technology knowledge is displayed below.

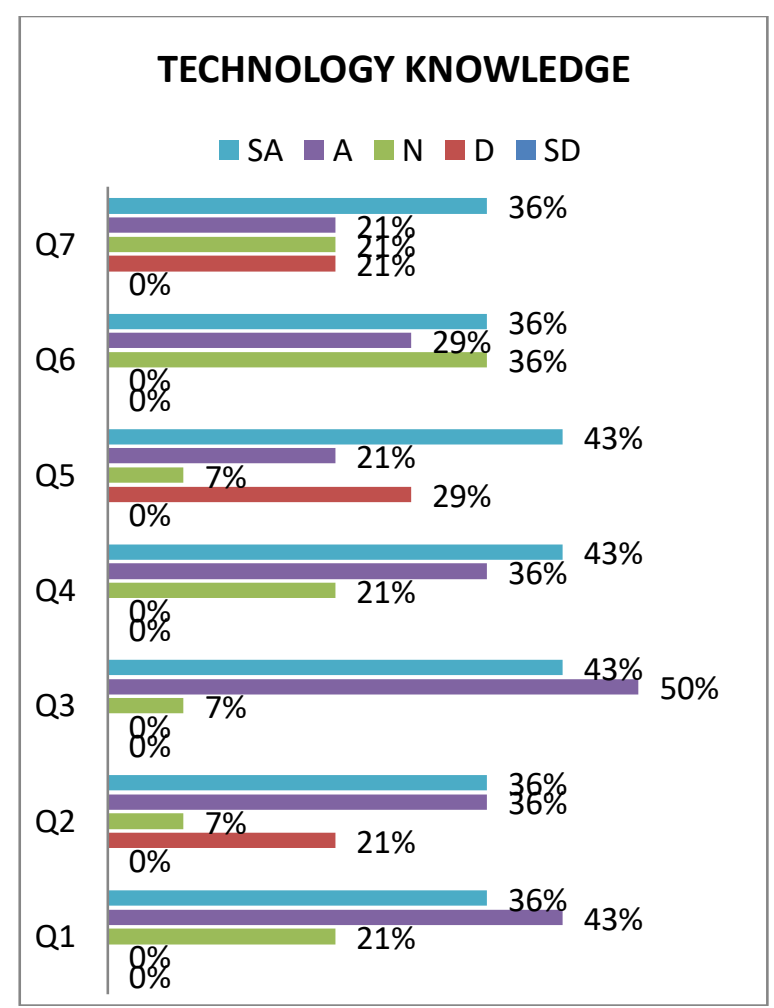

Figure 1. Technology Knowledge Source: Ammade, 2019

These findings highlight the research subjects' levels of technology knowledge. The first statement on the survey covers whether respondents know how to solve technical problems, and the results showed $36 \%$ of respondents strongly agreed that they could, and $43 \%$ of them agreed. So, the result suggested much knowledge of solving technical problems in technology (79\%). However, $21 \%$ of the total respondents took a neutral position, meaning they are not sure whether they can solve technical problems. The good finding on this statement illustrated 
that none of the research subjects were illiterate in solving technical problems.

The second statement in technology knowledge deals with learning technology easily. As shown above, ten of the 14 respondents $(72 \%)$ stated they can learn technology easily, $7 \%$ were neutral, while $21 \%$ took the disagree option. The third statement concerns keeping up with important new technologies, and the results showed a high percentage in agreement point - $93 \%$ of respondents update on important new technologies, and none is categorized as not updating. The results indicating respondents' knowledge of new technologies is categorized very well. The fourth statement in this survey asks whether respondents frequently play around with technology. As displayed on the above chart, the frequency rate is medium, with $43 \%$ on strongly agree and $36 \%$ on agree. Still, $21 \%$ take the neutral position, which means they are touching on technology, but not using it frequently.

The fifth statement interrogates knowing about a lot of different technologies. Here, the results indicate almost half of research subjects (43\%) in the strongly agree position, and $21 \%$ on agree. In this illustrationspecified research, subjects recognized different kinds of technology, although $29 \%$ of them still have limited knowledge of technology types. The sixth statement in the survey concerns having the technical skills needed to use technology, and the results demonstrated a similar point, with $65 \%$ of the subjects stating they have the necessary technical skills to use technology, and 36\% remaining neutral. The good point is that none of them are categorized as illiterate in the technical skills to operate technology. This indicates they can operate technology, and are able to fix technical technological problems.

The seventh statement in the technology knowledge session concerns having had sufficient opportunities to work with different technologies. The respondents seem to have similar percentages in each option $36 \%$ strongly agree, $21 \%$ agree, $21 \%$ were neutral, and $21 \%$ disagree. The findings show a balance between the numbers of respondents who have adequate chances to work with various types of technology, versus those who do not have such opportunities.

\section{Content Knowledge (CK)}

The survey on content knowledge covers three research questions, and data findings can be seen below.

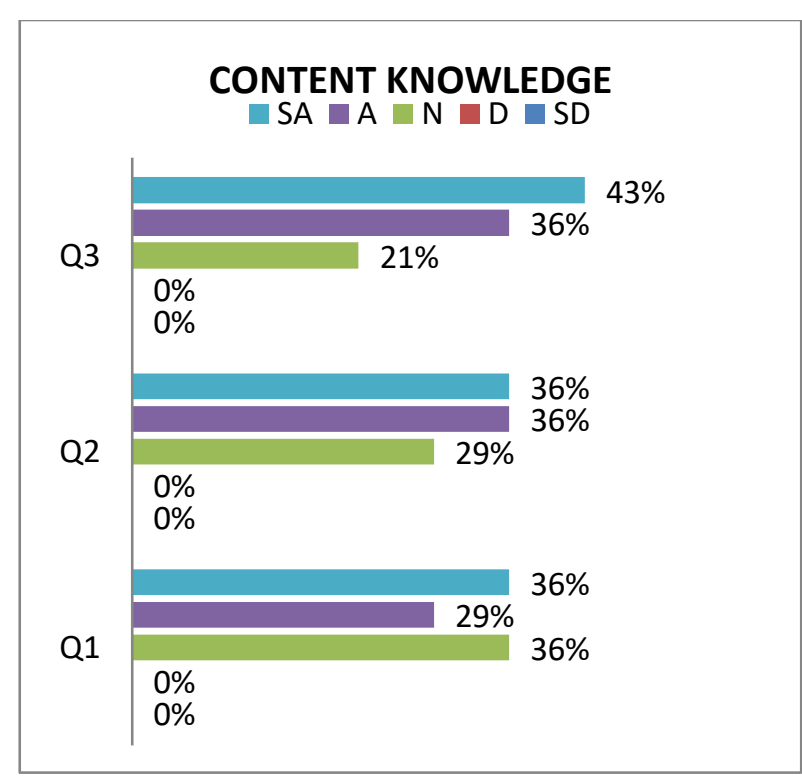

Figure 2. Content Knowledge Source: Ammade, 2019

The first question asks about having sufficient knowledge about English (See attachment) Here, the data findings show $65 \%$ respondents believe their English knowledge can be categorized as adequate. However, 36\% are unsure about whether they have enough English knowledge. The reassuring news is that none of respondents categorizes himself or herself as having insufficient knowledge about English.

The second question deals with using the English way of thinking. Some of the research subjects felt they can do this very well (36\%), and some scored themselves as good (29\%). Still, there are respondents in a neutral position between using and not using the English way of thinking (36\%). None of them declared themselves to be never using the English way of thinking $(0 \%)$. 
The last question queried whether respondents have various ways and strategies of developing an understanding of English; $79 \%$ agreed on this statement, although $21 \%$ opted for the neutral choice. The good thing is that none of them admitted not having various ways of - or being monotonous in developing their understanding of English $(0 \%)$.

\section{Pedagogical Knowledge (CK)}

In this part, the research subjects were questioned on their knowledge of pedagogical approaches to teaching. There are seven questions, including how to assess student performance, ability to adapt teaching based on what students currently understand or do not understand, ability to adapt teaching style to different learners, ability to assess student learning in multiple ways, ability of lecturers to employ a wide range of teaching approaches in a classroom setting, while familiar with students' common understandings and misconceptions, and knowing how to organize and maintain classroom management. This should reference the actual source of information. In this case, Figure 3.

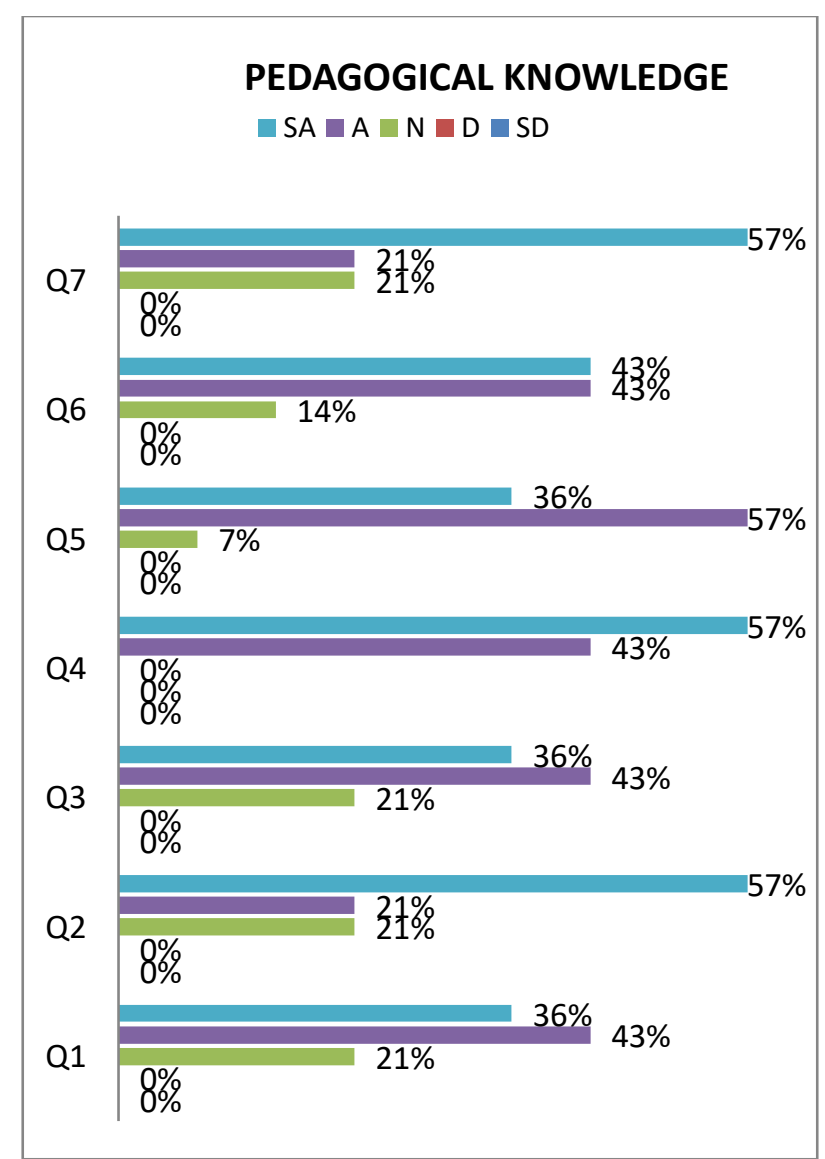

Figure 3. Pedagogical Knowledge Source: Ammade, 2019

Reference as figure 3, in question one, about knowing how to assess student performance in the classroom, results showed that the research subjects approved the statement, based on the frequency shown. There are $36 \%$ respondents who strongly agree with the statement, and $43 \%$ taking the agree option. However, $21 \%$ of respondents are still in a neutral position between knowing and not knowing how to assess student's performance in the classroom. Conversely, there is no respondent illiterate in assessing their students, which means they know how to measure their students' ability.

Regarding statement two on ability to adapt teaching based on what students currently understand or do not understand, $78 \%$ of the research subjects believe they can adapt their teaching based on their students' understanding. In the neutral position are $21 \%$ of the respondents. The good thing in this item is that all respondents can adapt their teaching based on their level of 
understanding of the students. On the item concerning ability to adapt teaching style to different learners (Q3), 36\% of respondents say they can adapt their teaching style very well, and $43 \%$ took the good option. The remaining $21 \%$ respondents put themselves between able and unable to adapt their teaching style to various learners. Conversely, none of respondents is categorized as unable to adapt.

The next survey item is the ability to assess student learning in multiple ways (Q4). In the chart, it is clearly displayed that $57 \%$ respondents strongly agree with the statement, and $43 \%$ of them agree on it. This means that here all respondents can evaluate their students' learning in many ways. Another item questioned in the survey is the ability of lecturers to use a wide range of teaching approaches in the classroom setting (Q5). As revealed in the findings chart, 93\% stated that they can use a wide range of teaching approaches during the teachinglearning process, and only $7 \%$ remain in the middle/neutral position between using and not using various teaching approaches in the classroom.

Regarding the penultimate statement in the survey, regarding familiarity with students' common understandings and misconceptions (Q6), the findings return a positive reaction, with $86 \%$ respondents approving the statement (strongly agree and agree positions) that they are accustomed to their students' understandings and misconceptions. Only 14\% of them remain neutral. Interestingly, none of respondents is unfamiliar with their students' comprehension, which means they are well acquainted with their students.

The last statement in the survey is about knowing how to organize and maintain classroom management. In these data findings, $57 \%$ of respondents strongly agree with the statement, and $21 \%$ agree. There are $21 \%$ for the neutral option, and none disagree with the statement. It is noted that here all research subjects know how to manage their classrooms in constructive ways.

\section{Technological, Pedagogical, Content Knowledge (TPACK)}

In this session, the core question is knowledge of technology, pedagogy, and content acknowledged by the research subjects. There are four items regarding the knowledge, and reference figure 4 is here.

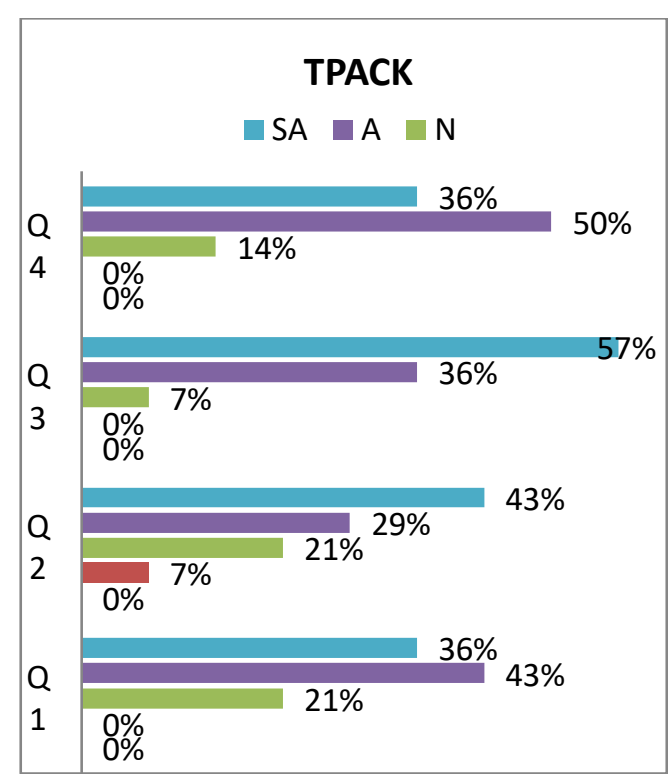

Figure 4. Technological, Pedagogical, Content Knowledge

Source: Ammade, 2019

The first statement in this TPACK part concerns the ability to teach lessons that appropriately combine English, technology, and teaching approaches. The findings clearly display that all research subjects can teach lessons using English, technology, and teaching approaches, with $36 \%$ responding strongly agree on being able to teach lesson using English, technology, and teaching approaches, and $43 \%$ respondents answering agree. Interestingly, $21 \%$ of the research subjects still cannot decide whether they can suitably combine their English, technology, and teaching approaches. The revealing data suggested that all of them admit they can implement the three knowledge areas (English, technology, and teaching) together. Concerning the second statement, on the ability to select technologies to use in the classroom that enhance what to teach, how to teach, and what students learn, the results provide moderate data. Respondents 
acknowledge that they can choose types of technology that support their teaching in the classroom $(72 \%)$, but $21 \%$ took the neutral option, and $7 \%$ disagreed with the statement.

The third statement concerns the ability to use strategies that combine content, technologies, and teaching approaches in the classroom. Most respondents agreed with the statement. They observed themselves using strategies to combine content, technology, and teaching approaches in their teaching settings $(93 \%)$. Yet $7 \%$ of respondents remain in the neutral option between being able and unable to use strategies that combine the knowledge of content, technology, and pedagogy.

The last statement in this survey is the ability to choose technologies that enhance the content of a lesson. In this finding, subjects opted for strongly agree (36\%), agree $(50 \%)$, and neutral $(14 \%)$. Here, all respondents already have the capability to select adequate technologies to improve their teaching, as revealed in the findings above.

\section{Model of TPACK}

The model of technological, pedagogical, and content knowledge (TPACK) comprises the last session in the survey. It consists of two statements, and it is about the respondents' previous experience. Reference figure 5 is here.

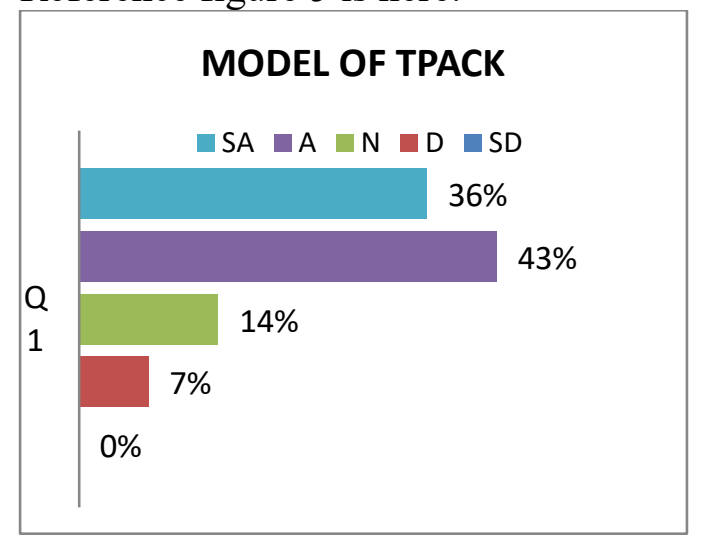

Figure 5. Model of TPACK

Source: Ammade, 2019

The first statement is about the effectiveness of the respondent's English language model in combining content, technologies, and teaching approaches in their teaching. As seen in the above graph, $36 \%$ of respondents chose strongly agree, $43 \%$ agree, and 14\% neutral that their English language teacher implemented a teaching model using a combination of content, technologies, and teaching approaches. Nonetheless, $7 \%$ of their teachers are still not implementing this model. This result shows that the model of TPACK is quite familiar to some teachers, although a few of them are still inexperienced in it.

The second statement concerns the frequency with which the respondent's previous teacher provided an effective model combining content, technologies, and teaching approaches in their teaching. The results are displayed below.

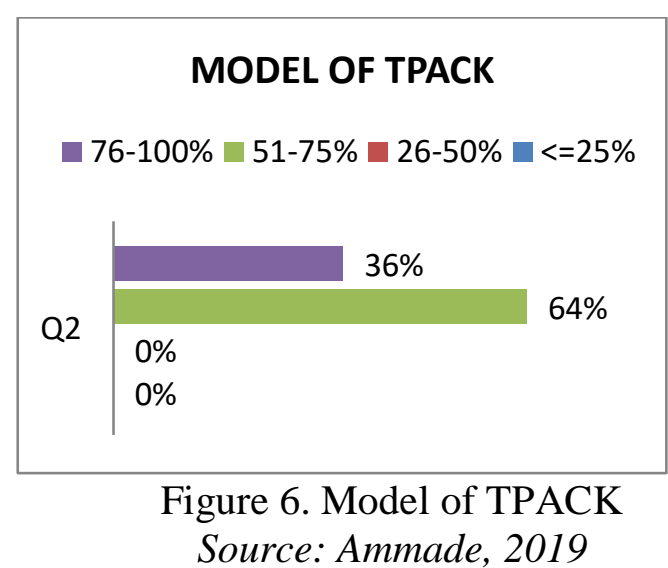

This should reference figure $6,36 \%$ of respondents were in the level of $76-100 \%$ provision of the TPACK model in their teaching, and $64 \%$ were in the level of 51$75 \%$. Surprisingly, none of the respondents chose a level of frequency below $50 \%$. This indicates that the TPACK model was implemented in their teaching days, though the term was not familiar in those times.

\section{DISCUSSION}

As the main focus of the study is on technology, pedagogy, and content knowledge integration in teaching, researching the knowledge level of the lecturers for each item (technology, pedagogy, content) is seen as necessary to strengthen the data. Besides, these data findings provide a review of deciding on a 
designed model of teaching writing. Resulting from the research findings on the respondents' levels of technological, pedagogical, and content knowledge, notes gathered on each item of the survey are discussed below.

\section{Technological Knowledge (TK)}

The research findings on technology knowledge covered knowing how to solve technical problems, learning technology easily, keeping up with important new technologies, frequency of playing around with the technology, knowing about a lot of technologies, having the technical skill needed to use technology, and having had sufficient opportunities to work with different technologies.

Here, the results of the findings suggest that most respondents have good literacy in technology knowledge. Their average frequency on all items is above $70 \%$, and none of them categorize as illiterate $(0 \%)$ on all items. The results reveal that all respondents are familiar enough with technology, either for technical problems in dealing with it, or technical skills needed to use it, including playing and updating new technology. As a result of the findings, in facing the era of industry 4.0, with its highuse technology settings, the respondents' knowledge of technology will be considered helpful in language teaching improvements, instead of being a major burden for respondents. The study by Aslan and Zhu (2016) indicates that teachers need to be competent in ICT integration to support their pedagogy process. Tinio (2003) stated a similar opinion, that technologies may assist in expanding access to education whenever and wherever it is needed.

\section{Content Knowledge (CK)}

In the section on content knowledge, three main items questioned in the survey cover having knowledge about English, the use of the English way of thinking, and having various ways and strategies of developing an understanding of English.

The results on content knowledge revealed average frequency on strongly agree, agree, and neutral positions. The respondents seem quite neutral about stating their knowledge on content. They classified themselves on content knowledge in a moderate position, neither highly knowledgeable nor low in expertise. However, the good thing on this data result is that respondents have adequate knowledge of their subject matter. They know how to teach their subject in good way, as supported by the study of Grabe and Kaplan (1996), and Pujianto, et. al (2014).

\section{Pedagogical Knowledge (PK)}

Pedagogical knowledge is knowledge on teaching strategies and methods of presenting the subject matter (Kanuka, 2006). In this survey, pedagogical knowledge of the research subject is highlighted through seven items. They are how to assess student performance, ability to adapt teaching based on what students currently understand or do not understand, ability to adapt teaching style to different learners, ability to assess student learning in multiple ways, ability of lecturers to use a wide range of teaching approaches in classroom settings, familiar with students' common understandings and misconceptions, and knowing how to organize and maintain classroom management.

The results of the findings in this part demonstrated similar percentages on each item. Statement numbers two and seven, for instance, scored the same percentages in the research findings. This means that the research subjects already have a parallel ability to adapt teaching based on their students' understanding, and on their own ability to know how to organize and maintain classroom management.

In other results, it is revealed that the research subjects know well how to assess their students' performance, including using multiple methods of evaluation. The ability to assess students' learning shown by this study's findings demonstrates that lecturers have adequate knowledge of pedagogy to support their teaching performance. Mouza, 
Karchmer-Klein, Nandakumar, Ozden, \& Hu (2014) identified ways to encourage the skills of technology and pedagogy towards better teaching through pedagogy competence improvement.

Other pedagogical knowledge that respondents excel at, based on the survey results, is the ability to adapt teaching styles to different learners, and to use a wide range of teaching approaches in classroom settings. This result showed the lecturers' strong knowledge in managing their teaching strategies, and this is one of the vital skills that are supposed to be mastered by educators.

\section{Technological, Pedagogical, Content Knowledge (TPACK)}

This part covered four research statements on the basis of technological, pedagogical, and content knowledge (TPACK). The statements posed to the respondents were concerned their ability to teach lessons that appropriately combine English, technology, and teaching approaches, their ability to select technologies to use in the classroom that enhance what to teach, how to teach, and what students learn, their ability to use strategies that combine content, technologies, and teaching approaches in the classroom, and their ability to choose technologies that enhance the content of a lesson.

The results of data research illustrate that the respondents' ability to teach lessons that combine the three core areas of knowledge pedagogy, content, technology - can be categorized in a moderate position. They are not yet expert in combining all the three core knowledge areas very well, but already recognize the approach, and sometimes implement it when teaching their classes. The same applies to their ability to choose appropriate technologies in the classroom that enhance what to teach, how to teach, and what students learn. They admitted that in this area, they are on the modest side. They know technologies, and use them in teaching, but have not fully involved them in the teaching-learning process. They just use them as teaching material sources or to present material in class. However, they have good literacy on technology that can support them in advancing their own teaching professionalism through TPACK training. A study by Khan (2014) on using TPACK as part of professional development of teachers in Bangladesh can be noted as good involvement of TPACK.

On the statement on the ability to use strategies combining content, technologies, and teaching approaches in the class, the respondents state that they know how to combine content, technology, and teaching approaches in classroom settings. However, they still employ this on an average level. They implement such strategies frequently when they are needed, although not as an integral part of their teaching. This seems good, but will be better if the lecturers can maximize the use of this approach in the learning setting.

The knowledge the research subjects display in choosing technologies to enhance content for lessons, as shown in the findings, can be categorized as well executed. All respondents state that they can select technologies that enhance their teaching subject matter. Yet, the technologies chosen still, on the surface, carry out functions like searching among teaching materials, or interacting between lecturer and students. Therefore, workshops or training regarding technology for education could be the solution to this.

\section{CONCLUSION}

The present study was an early stage on my developmental research in developing TPACK based instruction in teaching writing. It is designed to measure the TPACK literacy of lecturers of the English Education Department at Universitas Muhammadiyah Parepare. The data gained represents an initial source for developing TPACK-based model instruction in teaching writing. The results of this investigation showed that the literacy of lecturers regarding TPACK is at a moderate level. Moderate level here is 
categorized as they can use the three core knowledge areas of TPACK - technology, pedagogy, and content - in teaching lessons, but the way they use does not link each other and they use it irregularly. In other word, the use of technology knowledge does not fit to content, and pedagogy of their subject. This fact is supported by lecturers' opinion that they sometimes combine the TPACK model, but they are unsure if they already choose an appropriate combination to address the whole core knowledge. Therefore, more trainings or workshops regarding TPACK application are suggested. Forum group discussion or knowledge sharing concerning technology, pedagogy, and content knowledge will be great option as well in supporting the knowledge enrichment on TPACK. For further research option, exploring the kinds of variables that may affect the TPACK literacy of lecturers will be great steps.

\section{ACKNOWLEDGMENTS}

I would like to express my sincere gratitude to my supervisors for their great assistance in writing this manuscript. Their major contribution supported me a great deal in finishing this article.

\section{REFERENCES}

Altun, T, \& Akyildiz, S. (2017). Investigating Student Teachers' Technological Pedagogical Content Knowledge (TPACK) Levels Based on Some Variables. European Journal of Education Studies, 3(5), 467-485. Retrieved from www.oapub.org/edu. doi: 10.5281/zenodo.555996

Aslan, A., \& Zhu, C. (2016). Influencing factors and integration of ICT into teaching practices of pre-service and starting teachers. International Journal of Research in Education and Science, 2(2), 359-370, https://doi.org/10.21890/ijres.81048

Chai, C. S., Koh, J. H. L., \& Tsai, C. C. (2010). Facilitating preservice teachers' development of technological, pedagogical, and content knowledge

(TPACK). Educational Technology \& Society, 13(4), 63-73.

Gall, M. D., Gall, J.P., \& Borg, W.R. (2003). Educational Research: An Introduction ( $7^{\text {th }}$ edition). Boston: Ally \& Bacon

Grabe, W., \& Kaplan, R. (1996). B. Theory and Practice of Writing. An Applied Linguistic Perspective, 32-42.

Kanuka, H. (2006). Instructional design and e-learning: A discussion of pedagogical content knowledge as a missing construct. The e-Journal of Instructional Science and Technology, 9(2). [online]. Retrieved January 25, 2018, from http://www.usq.edu.au/electpub/ejist /docs/vo19_no2/papers/full_papers/k anuka.htm

Khan, S. H. (2014). A model for integrating ICT into teacher training programs in Bangladesh. International Journal of Education and Development using Information and Communication Technology, 10 (3), 21-31.

Kumar, R. (2005). Research Methodology-A Step-by-Step Guide for Beginners. London, Thousand Oaks CA, New Delhi, Singapore: Sage Publications.

Mishra, P., \& Koehler, M. J. (2006). Technological pedagogical content knowledge: A framework for teacher knowledge. Teachers college record, 108(6), 1017-1054.

Mouza, C., Karchmer-Klein, R., Nandakumar, R., Ozden, S.Y., \& Hu, L. (2014). Investigating the Impact of An integrated Approach to the Development of Preservice Teachers' Technological Pedagogical Content Knowledge (TPACK). Computers \& Education, 71, 206-221.

Pujianto, D., Emi, E., \& Sudarsono, M.I. (2014). A Process-Genre Approach to Teaching Writing Report Text to Senior High School. Indonesian Journal of Applied Linguistics. 4 (1), 99-110 
Schmidt, D. A., Baran, E., Thompson, A. D., Mishra, P., Koehler, M. J., \& Shin, T. S. (2009). Technological pedagogical content knowledge (TPACK) the development and validation of an assessment instrument for preservice teachers. Journal of Research on Technology in Education, 42(2), 123149.

Shulman, L.S. (1986). Those who Understand: Knowledge Growth in Teaching. Educational researcher, 15, 4-14.

Tinio, V. L. (2003). ICT on Education. Retrieved November 3, 2016, from www.eprimers.org:

www.eprimers.org

\section{APPENDIX}

Taken from the survey by Schmidt, Baran,

Thomson (2009)

\section{SURVEY OF TEACHERS' KNOWLEDGE OF TEACHING AND TECHNOLOGY}

Thank you for taking time to complete this questionnaire. Please answer each question to the best of your knowledge. Your thoughtfulness and candid responses will be greatly appreciated. Your individual name or identification number will not at any time be associated with your responses. Your response will be kept completely confidential and will not influence your course grade.
Demographic Informatiom

1. Your email address :

2. Gender
a. Female
b. Male

3. Age range
a. $20-30$
b. $31-40$
c. $41+$

4. Major
a. English
b. Non English

5. Area of Specialization
a. Art
b. Early Childhood Education Unified with Special Education
c. English and language Arts
d. Foreign Language
e. Health
f. History
g. Instructional Strategist : Mild/Moderate Endorsement
h. Mathematics
i. Music
j. Science-Basic
k. Social Studies
1. Speech/Theater
m. Other

6. Are you completing an educational computing minor?
a. Yes
b. No

\section{TECHNOLOGY KNOWLEDGE (TK)}

Strongly Disagree $=$ SD Disagree $=$ D Neither Agree $/$ Disagree $=$ N Agree $=$ A Strongly Agree $=S A$

1. I know how to solve my own technical problems

2. I can learn technology easily.

3. I keep up with important new technologies.

4. I frequently play around with the technology.

5. I know about a lot of different technologies.

6. I have the technical skills I need to use technology.

7. I have had sufficient opportunities to work with different technologies.
SD D N A SA
SD D $\mathrm{N}$ A $\mathrm{SA}$
SD D N A SA
SD D N A SA
SD D N A SA
SD D N A SA
SD D N A SA

\section{CONTENT KNOWLEDGE (CK)}

\section{English}

1. I have sufficient knowledge about English

2. I can use English way of thinking

3. I have various ways and strategies of developing my undersanding of English

$\begin{array}{lllll}\text { SD } & \text { D } & \text { N } & \text { A } & \text { SA } \\ \text { SD } & \text { D } & \text { N } & \text { A } & \text { SA } \\ \text { SD } & \text { D } & \text { N } & \text { A } & \text { SA }\end{array}$


1. I know how to assess student performance in classroom

2. I can adapt my teaching based upon wwhat students Currently undersand or dO not understand .

3. I can adapt my teaching style to different learners.

4. I can assess student learning in multiple ways.

5. I can use a wide range of teaching approaches in classroom setting.

6. I am familiar with common student understandings and misconceptions.

7. I know how to organize and maintain classroom management.

$\begin{array}{lllll}\text { SD } & \text { D } & \text { N } & \text { A } & \text { SA } \\ \text { SD } & \text { D } & \text { N } & \text { A } & \text { SA } \\ & & & & \\ \text { SD } & \text { D } & \text { N } & \text { A } & \text { SA } \\ \text { SD } & \text { D } & \text { N } & \text { A } & \text { SA } \\ \text { SD } & \text { D } & \text { N } & \text { A } & \text { SA }\end{array}$

$\mathrm{SD} \quad \mathrm{D} \quad \mathrm{N} \quad \mathrm{A}$ SA

SD $\quad \mathrm{D} \quad \mathrm{N} \quad \mathrm{A} \quad \mathrm{SA}$

\section{TECHNOLOGICAL PEDAGOGICAL CONTENT KNOWLEDGE (TPACK)}

Strongly Disagree $=$ SD Disagree $=D$ Neither Agree $/$ Disagree $=$ N Agree $=A$ Strongly Agree $=S A$

1. I can teach lessons that appropriately combine
English, technologies, and teaching approaches

$\begin{array}{lllll}\text { SD } & \text { D } & \text { N } & \text { A } & \text { SA } \\ \text { SD } & \text { D } & \text { N } & \text { A } & \text { SA }\end{array}$

2. I can select technologies to use in my classroom that enhance what I teach, how I teach, and what students learn.

3. I can use strategies that combine content, technologies, and teaching approaches that I learned about in my coursework in my classroom.

4. I can choose technologies that enhance the Content for a lesson.

$\begin{array}{lllll}\mathrm{SD} & \mathrm{D} & \mathrm{N} & \mathrm{A} & \mathrm{SA}\end{array}$

\section{MODEL OF TPACK}

Strongly Disagree $=$ SD Disagree $=D$ Neither Agree $/$ Disagree $=$ N Agree $=$ A Strongly Agree $=S A$
1. My English language teacher appropriately model
SD D N
A SA
Combining content, technologies, and teaching approaches in their teaching.

1. In general, appropriately what percentage of Your teacher have provided an effective model of combining content, technologies, and teaching Approaches in their teaching?

$25 \%$ or Less than $25 \%$

$26 \%-50 \%$

$51 \%-75 \%$

$76 \%-100 \%$

2. Describe a specific episode where an instructor effectively demonstrated or modeled combining content, technologies, and teaching approaches in aclassroom lesson. Please include in your descrtiption what content was being taught, what technology was used, and what teaching approach (es) was implemented. 